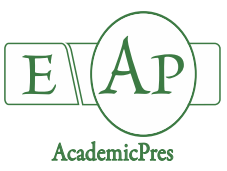

Inan M (2021)

Notulae Botanicae Horti Agrobotanici Cluj-Napoca

Volume 49, Issue 1, Article number 12171

DOI: $10.15835 /$ nbha 49112171

Research Article

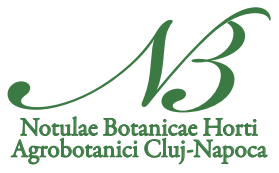

\title{
Seasonal variation of fatty and essential oil in terebinth (Pistacia terebinthus L.) fruit
}

\section{Memet INAN*}

Adryaman University, Faculty of Agricultural Sciences and Technologies, Department of Agricultural Engineering, 02400

Adryaman,Turkey; minan@adiyaman.edu.tr (*corrsponding author)

\begin{abstract}
A member of Anacardiaceae family, terebinth (Pistacia terebinthus L.) is a perennial tree that is evergreen. Terebinth is spread on a very wide area in Turkey, from the Mediterranean costs to South-Eastern Anatolia. In the present study, to determine seasonal variation of fatty oil and essential oil in terebinth fruits, harvests were made when the fruit colour was Green (GF), Red (RF), Red-Black (RBF) and Black (BF). Upon ripening, fatty oil rate in the fruit raised from $13.40 \%$ to $37.08 \%$, while essential oil rate reduced from $0.116 \%$ to $0.082 \%$. In all growth periods, oleic, linoleic and palmitic acids made-up the main composition of the oil, and through growth there was increase in the amounts of oleic and palmitic oil acids while a decrease was reported in linoleic acid rate. In terms of essential oil compounds, $\alpha$ - pinene, limonene, p-cymen-8-ol and panisaldehyde composed the main compounds, the highest $\alpha$ - pinene rate was observed during BF period as $37.23 \%$, the highest limonene rate was observed during RBF period as $22.01 \%$, while the highest p-cymen-8-ol and panisaldehyde rates have been observed during the GF harvest period by $11.29 \%$ and $7.25 \%$, respectively. In conclusion is that the fruit should be harvested during the black fruit colour, when the fruit is fully ripened, in order to get a good quality fruit and aroma and people picking the fruit from nature should be trained about this.
\end{abstract}

Keywords: essential oil composition; fruit oil; fatty acids; ontogenetic variability; terebinth

\section{Introduction}

Pistacia terebinthus $\mathrm{L}$. is a perennial tree spreading naturally from the Mediterranean to West Asia (Kavak et al., 2010). And in Turkey, it can grow naturally in a wide area covering Mediterranean, Aegean, Black Sea and Southeastern Anatolia Regions (Tufan et al., 2017). Turpentine chi Otica (gum) is obtained by opening the wound in the trunk of the tree. This terebentin has a pleasant odour, has the consistency of honey, is transparent with a light yellow colour melts easily in alcohol. Gallnut, formed by some insects on plant leaves, carry high amounts of tannin. Such gallnut is used to dye valuable silk fabrics, to colour wine and also used as incense material (GDF, 2019). Young shoots and fruits are used for nutrition. The fruits have been used as an appetiser in human nutrition in southern Turkey for several thousand years. As a folk medicine, the decoction of its leaves is used in gastric treatments and its fruits are used for the treatment of gastralgia (internally), rheumatism, coughs (externally), and as a stimulant, diuretic, anti-tussive and anti-rheumatic (Ozcan, 2004).

Received: 27 Nov 2020. Received in revised form: 08 Mar 2021. Accepted: 09 Mar 2021. Published online: 10 Mar 2021.

From Volume 49, Issue 1, 2021, Notulae Botanicae Horti Agrobotanici Cluj-Napoca journal will use article numbers in place of the traditional method of continuous pagination through the volume. The journal will continue to appear quarterly, as before, with four annual numbers. 
In Turkey, fruits of this plant are roasted and marketed as dry fruit or grinded and sold as "terebinth (meningic) coffee". Furthermore, oil extracted from its fruits is used in making soap (Baytop, 1999). Terebinth fruits are rich in oil containing high concentrations of unsaturated fatty acids and carotenoids, phenolic compounds and tocopherols, tannin and resinous substances, and dietary fiber (Matthäus and Ozcan, 2006; Kizll and Turk, 2010).

Studies related to fatty oil in the fruit led to the conclusion that oil ratio ranges between $38.74-47.0 \%$ and oleic, palmitic and linoleic oil acids are the main oil acids (Ozcan, 2004; Matthäus and Ozcan, 2006; Kizll and Turk, 2010; Durmaz and Gokmen, 2011; Kaya and Ozer, 2015).

Essential oil is present in the leaves, young suckers, flower and fruits of terebinth plant. Essential oil rates and the main components of this oil, such as limonene, $\beta$ - pinene and $\alpha$-pinene have been observed at different rates during different growth periods of the plant (Couladis et al., 2003; Pulaj et al., 2016). This change in the essential oil rates and its components was present during harvest seasons too. A study conducted by Zrira et al. (2003) on the leaves and flowers of $P$. lentiscus cultivar from the same family reported significant differences between essential oil and its components. It has been similarly observed that the essential oil rates of fruits from plants grown in different locations in their natural environments ranged between 0.08- 0.16\% (Ozcan et al., 2009).

Growing naturally in South Eastern Region of Turkey, terebinth trees are used as rootstock and are grafted with Pictacia vera vaccine. This, however, causes a reduction in terebinth population. Furthermore, terebinth fruits are picked without any regulations and sold in domestic and international markets (Inan and Harbi, 2018). Uncontrolled and untimely picking leads to a change in the quality and aroma (especially in terebinth coffee production) if fruits are picked before ripening, and to a reduced yield in late picking. The purpose of this study was to determine the oil contained in terebinth fruits during different growth periods (ontogenetic variability) as well as the composition of fatty, essential oil and its components.

\section{Materials and Methods}

\section{Plant material}

Fruits of the Pistacia terebinthus L. cultivar spreading naturally Nemrut Mountain National Park in Adiyaman province in the south eastern Anatolian region of Turkey $\left(37^{\circ} 56^{\prime} 33^{\prime \prime} \mathrm{N}, 38^{\circ} 39^{\prime} 27^{\prime \prime} \mathrm{E}\right.$ and altitude $819 \mathrm{~m}$ ) composed the material of this study. Fruits have been picked from the same tree in 4 different periods; at the beginning of ripening, when green (GF: green fruit) (23.08.2018), red (RF: red fruit) (07.09.2018), redblack (RBF: red-black fruit) (20.09.2018) and when fully ripened in black (BF: black fruit) colour (01.10.2018). Harvested fruits have been dried at room temperature (Figure 1).

\section{Fatty oil rate}

After being dried at room temperature, the collected fruits have been grinded, $5 \mathrm{~g}$ of sample has been taken with 3 repetitions for each harvest period and subjected to 6 hours of extraction in Soxhlet system. The solvent used in the system was petroleum ether. At the end of the duration, balloons have been kept at a 105 ${ }^{\circ} \mathrm{C}$ stove for 1 hours, before being cooled in a desiccator. Then the samples have been weighed and the results converted into $\%$.

\section{Fatty acid composition}

$100 \mu \mathrm{l}$ samples have been taken from oils extracted in each harvest season, $\mathrm{KOH}$ solution with $3 \mathrm{ml} \mathrm{N}$ Heptan and $400 \mu \mathrm{l} 2 \mathrm{~N}$ methanol has been added and following esterification, fatty components have been defined at the Mustafa Kemal University, Faculty of Agriculture, Department of Field Crops Medical and Aromatic Crops Analysis Laboratory through gas-chromatographic method. Defining the fatty oil components was performed by using a Thermo Scientific ISQ Single Quadrupole gas-chromatography device under the 
following conditions. A TG-Wax MS, 5\% Phenyl Polysilphenylene-silohexane column with a $0.25 \mathrm{~mm}$ internal diameter $\times 60 \mathrm{~m}$ length, $0.25 \mu \mathrm{m}$ film thickness has been used. Carrier gas used in the study was helium $(99,9 \%)$ with a flow rate of $1 \mathrm{~mL} \mathrm{~m}^{-1}$. Ionization energy has been set as $70 \mathrm{eV}$ and mass interval has been set as $\mathrm{m} \mathrm{z}^{-1} 1,2-$ 1200 amu. Scan mode has been used for data collection. MS transfer line temperature was $250{ }^{\circ} \mathrm{C}$, MS ionization temperature was $220^{\circ} \mathrm{C}$, injection port temperature was $220^{\circ} \mathrm{C}$, and column temperature was 50 ${ }^{\circ} \mathrm{C}$ at the beginning and then raised up to $220^{\circ} \mathrm{C}$ with a temperature increase rate of $3{ }^{\circ} \mathrm{C} \mathrm{m}^{-1}$. The structure of each compound has been identified with Xcalibur progam, by using mass spectrums (Wiley 9 ).

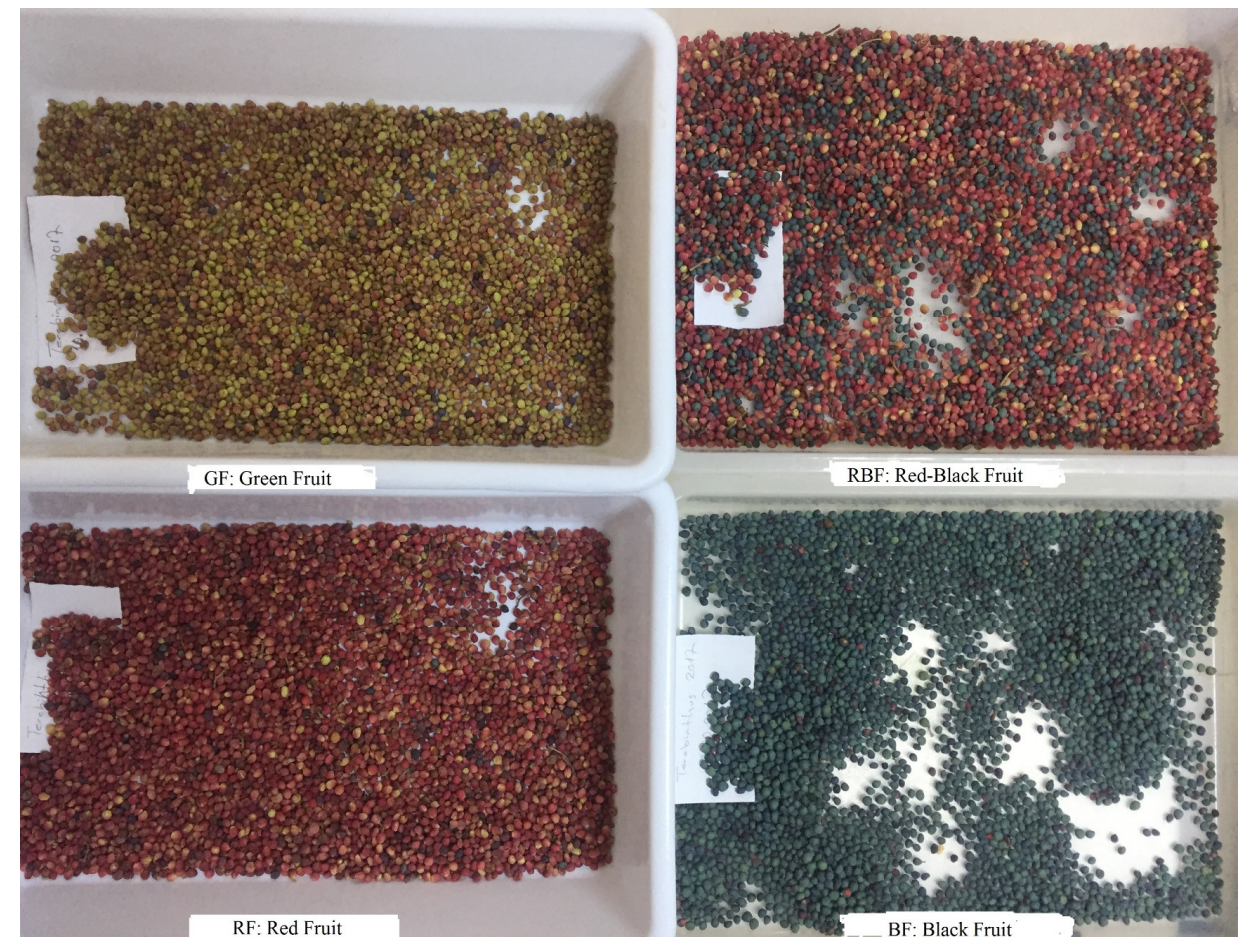

Figure 1. Green (GF), Red (RF), Red-Black (RBF) and Black turpentine fruits

\section{Essential oil rate}

Fruits were air-dried in the shade at room temperature and then extracted separately using hydrodistillation method for $3 \mathrm{~h}$ in Clavenger type apparatus. Essential oils were dried over anhydrous sodium sulfate and stored in the dark vials at $-4^{\circ} \mathrm{C}$, until analyzed.

\section{Gas chromatography-mass spectrometry analysis (GC-MS) of the essential oils}

The GC-MS analysis were carried out with Thermo Scientific ISQ Single Quadrupole model device. A TG-Wax MS model column (5\% Phenyl Polysilphenylene-siloxane, 0,25 mm inside diameter $30 \mathrm{~m}$ in length, having $0,25 \mu \mathrm{m}$ film thickness) was used with the carrier gas helium. The MS transfer line temperature was set to $250^{\circ} \mathrm{C}$, MS ionization temperature was set to $220^{\circ} \mathrm{C}$. The column temperature starts at $50^{\circ} \mathrm{C}$ and has risen up to $220^{\circ} \mathrm{C}$ with $3{ }^{\circ} \mathrm{C} \mathrm{min}{ }^{-1}$ temperature rise rate. The split ratio was set to $10: 1$ Mass spectra were recorded at $70 \mathrm{eV}$; the mass range was from 1,2-1200 $\mathrm{m} \mathrm{z}^{-1}$. Scan Mode has been used in data collection. Structure of each compound has been defined by the Xcalibur program by using mass spectrums.

\section{Statistical analyses}

Thousand seed weight and oil rate data obtained in harvest periods have been subjected to variance analysis with a randomized blocks experimental design by using Mstatc analysis program. 


\section{Results and Discussion}

P. terebinthus fruits were picked starting from the second half of July. Thousand seed weights, oil and essential oil rates of the picked fruits are provided in Table 1. Statistically meaningful differences have been observed between the harvest periods in terms of thousand seed weights and oil rates. The highest thousand seed weight and oil rate have been respectively observed as $58.25 \mathrm{~g}$ and $37.08 \%$ at full ripening period (in black fruits). The lowest values, on the other hand, have been observed as $33.3 \mathrm{~g}$ and $13.40 \%$ during the first harvest when fruits were green in color. Something quite the contrary has been observed in essential oil rates. Essential oil rate in fruits started to reduce with ripening. The highest essential oil rate $(0.116 \%)$ has been observed during GF harvest period, and no statistically meaningful difference has been observed between the essential oil rates (between $0.093 \%$ and $0.088 \%$ respectively) in RF and RBF harvest seasons. The lowest essential oil rate $(0.082 \%)$ has been observed during the $\mathrm{BF}$ harvest season.

Table 1. The effects of different harvest periods on thousand seed weight, fatty oil and essential oil rates of P. terebinthus fruits

\begin{tabular}{|l|c|c|c|c|}
\hline $\begin{array}{c}\text { Harvest } \\
\text { period }\end{array}$ & $\begin{array}{c}\text { Harvest } \\
\text { date }\end{array}$ & $\begin{array}{c}\text { Thousand seed } \\
\text { weight }(\mathrm{g})\end{array}$ & $\begin{array}{c}\text { Fatty oil rate } \\
(\%)\end{array}$ & $\begin{array}{c}\text { Essential oil rate } \\
(\%)\end{array}$ \\
\hline GF: Green fruit & 23.08 .2018 & $33.30 \mathrm{~d}$ & $13.40 \mathrm{~d}$ & $0.116 \mathrm{a}$ \\
\hline RF: Red fruit & 07.09 .2018 & $36.23 \mathrm{c}$ & $19.27 \mathrm{c}$ & $0.093 \mathrm{~b}$ \\
\hline RBF: Red-black fruit & 20.09 .2018 & $42.48 \mathrm{~b}$ & $33.04 \mathrm{~b}$ & $0.088 \mathrm{bc}$ \\
\hline BF: Black fruit & 01.10 .2018 & $58.25 \mathrm{a}$ & $37.08 \mathrm{a}$ & $0.082 \mathrm{c}$ \\
\hline LSD $(1 \%){ }^{*}$ & 0.96 & 2.04 & 0.0095 \\
\hline
\end{tabular}

Our findings related to thousand seed weight and oil rates are lower than those reported by Ozcan (2004), Kizil and Turk (2010), and Kaya and Ozer (2015). Thousand seed weights defined by us in RBF and BF harvest periods are higher than those reported by Gultekin et al. (2007). Ozcan et al. (2009) collected ripened fruits from different locations with essential oil rates ranging between $0.08-0.16 \%$, and in a similar study, Pulaj et al. (2016) reported a range between 0.02-0.12\%. Essential oil rates observed by us are within these values. Couladis et al. (2003) reported an essential oil rate of $0.54 \%$ in non-ripened fruits, and a rate of $0.73 \%$ in ripened fruits. These values are much higher than our findings. However, the essential oil rate observed by us at the GF harvest period is higher than those reported by Ozcan (2004) and Kizil and Turk (2010). The differences between our study findings and the above examples are probably due to collecting the materials from different locations, age of the crops, harvest periods, climate and soil conditions.

\section{Fatty acid composition}

Oil acid variations, as observed in oils extracted from $P$. terebinthus fruits in different harvest periods, are given in Table 2. In all four harvest periods, oils extracted from fruits have been observed to contain 7 oil acids with a ratio of over $1 \%$. Oleic, linoleic and palmitic acids compose the main compositions of oil. With ripening, there was an increase in oleic, palmitic, palmitoleic and stearic acid contents, and a decrease in linoleic, cis-13-octadecenoic and linolenic acids. The highest oleic acid content has been observed in fruits picked during the BF period by $46.13 \%$, while the lowest ratio has been observed in the RF period fruits by $41.67 \%$. Something similar has also been observed in palmitic acid. Observed at a rate of $18.78 \%$ during the GF period, palmitic acid content became as high as $20.31 \%$ at the BF period. However, the $25.71 \%$ linoleic acid content at the GF period receded to $18.15 \%$ at the BF period (Figure 2). This is a significant indicator as it confirms that the oil composition of fruit varies in different growth periods.

Studies related to fruit oil report that in terms of unsaturated fatty acids, oleic acid content varies between 34.80-55.16\% and linoleic acid content ranges between 16.22-29.64\%, and in terms of saturated fatty 
acids, palmitic acid content varies between 13.67-25.67\% (Ozcan, 2004; Kiz1l and Turk, 2010; Durmaz and Gokmen, 2011; Durak and Ucak, 2015; Tufan et al., 2017).

Table 2. The effects of different harvest periods on the fatty acid compositions (\%) of P. terebinthus fruits

\begin{tabular}{|l|c|c|c|c|}
\hline \multicolumn{1}{|c|}{ Fatty Acid } & GF & RF & RBF & BF \\
\hline Palmitic acid (C16:0) & 18.78 & 18.19 & 19.78 & 20.31 \\
\hline Palmitoleic acid (C16:1) & 2.34 & 3.35 & 3.17 & 4.04 \\
\hline Stearic acid (C18:0) & 2.28 & 2.72 & 3.26 & 3.65 \\
\hline Oleic Acid (C18:1) & 42.87 & 41.67 & 43.32 & 46.13 \\
\hline cis-13-octadecenoic (13c-18:1) & 2.69 & 2.13 & 0.24 & 0.69 \\
\hline Linoleic acid (C18:2) & 25.71 & 24.80 & 23.12 & 18.15 \\
\hline Linolenic acid (C18:3) & 1.05 & 1.43 & 1.00 & 0.42 \\
\hline Total & 95.72 & 94.29 & 93.89 & 93.39 \\
\hline
\end{tabular}

GF: Green Fruit, RF: Red Fruit, RBF: Red-Black Fruit, BF: Black Fruit

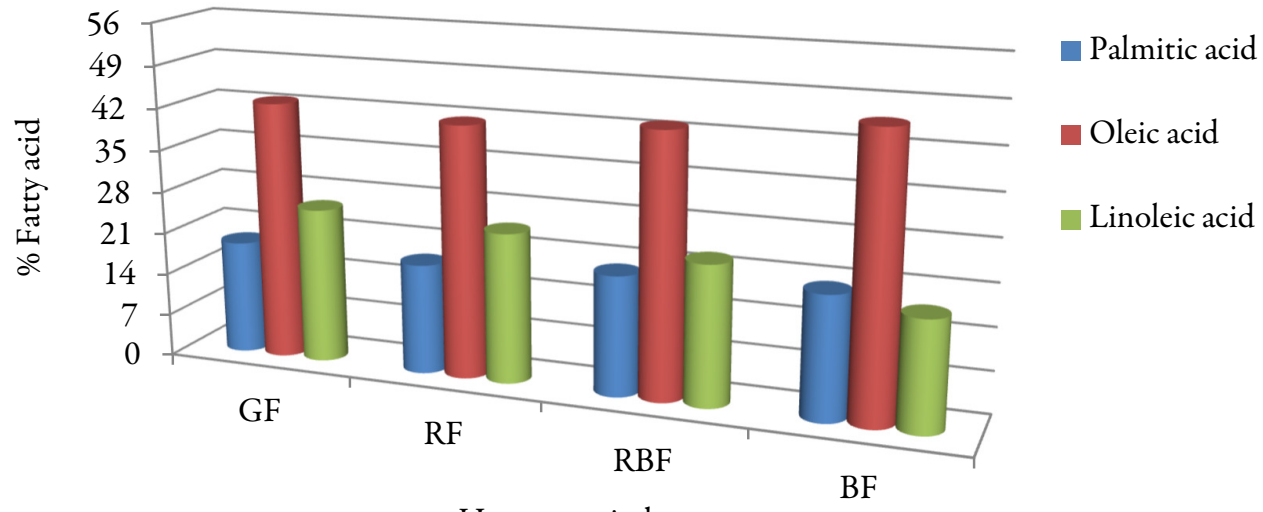

Harvest period

Figure 2. Some important fatty acid changes in the oil obtained from the P. terebinthus fruits according to the harvest times; GF: Green Fruit, RF: Red Fruit, RBF: Red-Black Fruit, BF: Black Fruit

\section{Essential oil components}

The essential oil components from the $P$. terebinthus fruits harvested in different growth periods are given in Table 3. As the fruit ripened, components such as $\alpha$-pinene, limonene, o-cymene, verbenol and $\alpha$ terpineol had an increased content while others such as $\beta$-pinene, piperitone, $d$-verbonen, caryophyllene oxid, spathulenol, p-anisaldehyde and 3-allylguaiacol were significantly reduced. Camphane, $\alpha$-campholene aldehyde and p-acetonylanisole went through an initial increase followed with a decrease at the final harvest period. Observed as a main component in all four harvest periods, $\alpha$ - pinene increased to $30.17 \%$ at RF period and then reached a top value at $\mathrm{BF}$ period by $37.23 \%$. Limonene, one of the other important components, kept raising from GF period (9.65\%) to RBF period (22.01\%) but was then reduced to $19.89 \%$ at the final harvest period. p-cymen-8-ol rate has been observed to be $11.29 \%$ at the first harvest period, and was reduced to $5.62 \%$ and $5.23 \%$ respectively at the RF and RBF periods, followed by a slight increase at the BF period, reaching $6.55 \%$. o-cymene rate increased as the fruit ripened and increased from 2.13\% to $7.54 \%$ (Figure 3). Pinocarvone and piperitone rates decreased to zero in BF period (Table 3). A study by Couladis et al. (2003) reported that the main components of the essential oils extracted from non-ripened and ripened fruits were limonene, $\beta$-pinene and $\alpha$-pinene respectively, and it also reported a decrease in limonene and $\alpha$-pinene components and increase in $\beta$-pinene component with ripening. Ozcan et al. (2009) reported different main components in the essential 
oils of terebinth fruits collected from different parts of Turkey, fruits picked from some areas had $\alpha$-pinene as the main component, while others had limonene, and there were also some with caryophyllene oxide and pcymene-8-ol as the main components, and they concluded that this could possibly be due to environmental and climactic conditions. The use of essential oil components as a flavorant in terebinth coffee is reportedly effective, and even though $\alpha$-pinene is the main component, other components are also contributing for the flavour and by roasting (cooking) the fruit, the rates of components may change (Gogus et al., 2011; Amanpour et al., 2019).

Table 3. The effects of different harvest periods on the essential oil components (\%) of P. terebinthus fruits

\begin{tabular}{|c|c|c|c|c|c|}
\hline & Component name & GF & RF & RBF & $\mathrm{BF}$ \\
\hline 1 & $\alpha$-Pinene & 31.28 & 30.17 & 34.12 & 37.23 \\
\hline 2 & Camphane & 1.25 & 1.23 & 2.01 & 0.38 \\
\hline 3 & $\beta$-Pinene & 1.86 & 1.92 & 1.00 & 0.51 \\
\hline 4 & $\beta$-Phellandrene & 0.56 & 0.32 & 0.30 & 1.22 \\
\hline 5 & Limonene & 9.65 & 18.23 & 22.01 & 19.89 \\
\hline 6 & o-Cymene & 2.13 & 2.21 & 3.21 & 7.54 \\
\hline 7 & $\alpha$-Campholene aldehyde & 0.23 & 0.21 & 1.24 & 0.19 \\
\hline 8 & Bornyl Acetate & 0.00 & 0.24 & 0.31 & 1.19 \\
\hline 9 & Pinocarvone & 1.12 & 1.25 & 0.48 & - \\
\hline 10 & Verbenol & 1.05 & 1.10 & 2.63 & 2.76 \\
\hline 11 & $\alpha$-Terpineol & 1.10 & 0.86 & 1.12 & 6.94 \\
\hline 12 & $\alpha$-Terpinyl acetate & 1.23 & 0.47 & 0.52 & 0.80 \\
\hline 13 & trans- Carveol & 1.32 & 0.23 & 0.32 & 0.89 \\
\hline 14 & p-Cymen-8-ol & 11.29 & 5.62 & 5.23 & 6.55 \\
\hline 15 & Piperitone & 2.43 & 1.10 & 0.98 & - \\
\hline 16 & D-verbonen & 3.98 & 3.03 & 3.00 & 2.58 \\
\hline 17 & Caryophyllene oxid & 2.93 & 2.85 & 0.23 & 0.16 \\
\hline 18 & Spathulenol & 3.86 & 3.45 & 2.98 & 2.02 \\
\hline 19 & p-Anisaldehyde & 7.25 & 7.00 & 3.25 & 2.13 \\
\hline 20 & 3-Allylguaiacol & 6.28 & 5.89 & 6.22 & 1.18 \\
\hline 21 & p-Acetonylanisole & 2.31 & 5.21 & 3.09 & 0.08 \\
\hline \multicolumn{2}{|c|}{ Total } & 93.11 & 92.59 & 94.25 & 94.24 \\
\hline
\end{tabular}

GF: Green Fruit, RF: Red Fruit, RBF: Red-Black Fruit, BF: Black Fruit

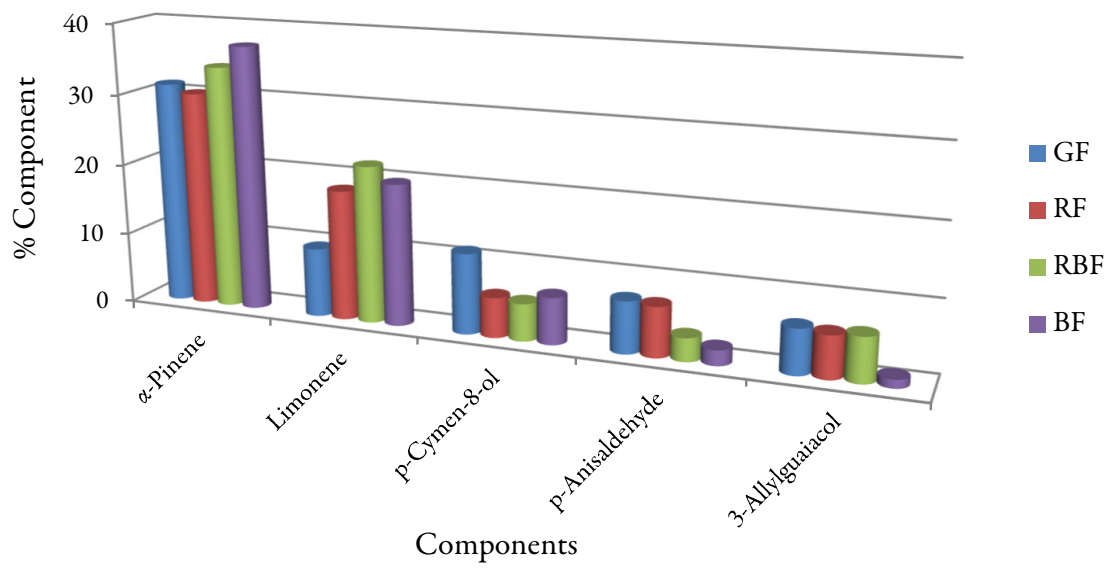

Figure 3. Some important components change in the essential oil obtained from the P. terebinthus fruits according to the harvest times 


\section{Conclusions}

It is known that the fatty and essential oil rates, fatty oil and essential oil components in terebinth fruit are affected by the region they are grown, climate conditions and soil structure. This study has examined the variations in these characteristics in different growing periods. It has been concluded that when terebinth is going to be used as coffee or dry fruit, crops must be harvested at the full-ripening (BF) period to ensure high quality fruits. This needs to be taken into consideration when picking from nature and the people picking terebinth fruits need to be trained about this issue.

\section{Authors' Contributions}

The author read and approved the final manuscript.

\section{Acknowledgements}

This research received no specific grant from any funding agency in the public, commercial, or not-forprofit sectors.

\section{Conflict of Interests}

The author declares that there are no conflicts of interest related to this article.

\section{References}

Amanpour, A, Guclu G, Kelebek H, Selli S (2019). Characterization of key aroma compounds in fresh and roasted terebinth fruits using aroma extract dilution analysis and GC-MS-olfactometry. Microchemical Journal 145:96104. https://doi.org/10.1016/j.microc.2018.10.024

Baytop T (1999). Türkiye'de Bitkiler ile Tedavi [Treatment plant in Turkey]. Nobel Medicine Publishing, Ankara, Turkey pp 324-325.

Couladis M, Ozcan M, Tzakou O, Akgul A (2003). Comparative essential oil composition of various parts of the turpentine tree (Pistacia terebinthus L.) growing wild in Turkey, Journal of the Science of Food and Agriculture 83:136-138. https://doi.org/10.1002/jsfa.1295

Durak MZ, Ucak G (2015). Solvent optimization and characterization of fatty acid profile and antimicrobial and antioxidant activities of Turkish Pistacia terebinthus L. extracts. Turkish Journal of Agriculture and Forestry 39:10-19. https://doi.org/10.3906/tar-1403-63

Durmaz G, Gokmen V (2011). Changes in oxidative stability, antioxidant capacity and phytochemical composition of Pistacia terebinthus oil with roasting. Food Chemistry 128:410-414. https://doi.org/10.1016/j.foodchem.2011.03.044

GDF (2019). Republic of Turkey General Directorate of Forestry. Retrieved 2019 January 31 from https://atib.ogm.gov.tr/Sayfalar/T\%C4\%B1bbi\%20ve\%20Itri\%20Bitkilerimizi\%20Tan\%C4\%B1yal\%C4\%B $1 \mathrm{~m} /$ Menengic.aspx.

Gogus F, Ozel MZ, Kocak D, Hamilton JF, Lewis AC (2011). Analysis of roasted and unroasted Pistacia terebinthus volatiles using direct thermal desorption-GCx GC-TOF/MS. Food Chemistry 129:1258-1264. https://doi.org/10.1016/j.foodchem.2011.05.003 
Gultekin HC, Deligoz A, Yildiz D, Gultekin UG, Genç M (2007). Influence of the sowing time and cold stratification on germination percent of trebinth tree (Pictacia terebinthus L.) seeds. Suleyman Demirel University Journal of Natural and Applied Sciences 11(3):225-231.

Inan M, Harbi M (2018). Adıyaman'da doğal yetişen bazı tıbbi ve aromatik bitkiler envanteri ve yönetim planlaması [Inventory and management planning of some naturally grown medicinal and aromatic plants in Adiyaman]. Gece Publishing, Turkey Chapter 5 pp 59-73.

Kavak DD, Altık E, Bayraktar O, Ulku S (2010). Pistacia terebinthus extract: As a potential antioxidant, antimicrobial and possible $\beta$-glucuronidase inhibitor. Journal of Molecular Catalysis B: Enzymatic 64:167-171. https://doi.org/10.1016/j.molcatb.2010.01.029

Kaya F, Ozer A (2015). Characterization of extracted oil from seeds of terebinth (Pistacia terebinthus L.) growing wild in Turkey. Turkish Journal of Science \& Technology 10(1):49-57.

Kızıl S, Turk M (2010). Microelement contents and fatty acid compositions of Rhus coriaria L. and Pistacia terebinthus L. fruits spread commonly in the south eastern Anatolia region of Turkey. Natural Product Research 24:92-98. https://doi.org/10.1080/14786410903132555

Matthäus B, Ozcan MM (2006). Quantitation of fatty acids, sterols, and tocopherols in turpentine (Pistacia terebinthus) growing wild in Turkey. Journal of Agriculture and Food Chemistry 54:7667-7671. https://doi.org/10.1021/jf060990t

Ozcan M (2004). Characteristics of fruit and oil of terebinth (Pistacia terebinthus L.) growing wild in Turkey. Journal of the Science of Food and Agriculture 84:517-520. https://doi.org/10.1002/jsfa.1632

Ozcan MM, Tzakou O, Couladis M (2009). Essential oil composition of the turpentine tree (Pistacia terebinthus L.) fruits growing wild in Turkey. Journal of Agricultural and Food Chemistry 114:282-285. https://doi.org/10.1021/jf060990t

Pulaj B, Mustafa B, Nelson K, Quave CL, Hajdari A (2016). Chemical composition and in vitro antibacterial activity of Pistacia terebinthus essential oils derived from wild populations in Kosovo. BMC Complementary and Alternative Medicine 16:147. https://doi.org/10.1186/s12906-016-1135-8

Tufan T, Arslan C, Das A (2017). Effects of terebinth (Pistacia terebinthus L.) fruit oil supplementation to diets on fattening performance, carcass characteristics, blood parameters and breast meat fatty acid composition in Japanese Quails (Coturnix coturnix japonica). Kafkas University Veterinary School Journal 23(2):289-295. https://doi.org.10.9775/kvfd.2016.16463
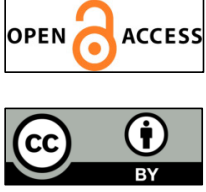

The journal offers free, immediate, and unrestricted access to peer-reviewed research and scholarly work. Users are allowed to read, download, copy, distribute, print, search, or link to the full texts of the articles, or use them for any other lawful purpose, without asking prior permission from the publisher or the author.

License - Articles published in Notulae Botanicae Horti Agrobotanici Cluj-Napoca are Open-Access, distributed under the terms and conditions of the Creative Commons Attribution (CC BY 4.0) License. (c) Articles by the authors; UASVM, Cluj-Napoca, Romania. The journal allows the author(s) to hold the copyright/to retain publishing rights without restriction. 